\title{
DETERMINATION OF REDUCING AND TOTAL SUGARS IN WEST INDIAN CHERRY (Malpighia Punicifolia, L.) JUICE
}

\author{
Rafael Santini, $J r^{1}$
}

\section{INTRODUCTION}

West Indian cherries are described by C. F. Asenjo and C. G. Moscoso $(1)^{2}$ as a small fruit which weighs about $4 \mathrm{gm}$. and its size varies from 0.5 to 1 inch in diameter. Its color ranges from light green, when immature, to deep bright red when ripe. There are three small seeds in each cherry, and about 80 percent of the weight of the fruit is edible. Asenjo and Freire de Guzmán (2) reported that West Indian cherries contained from 1 to $3 \mathrm{gm}$. of ascorbic acid per $100 \mathrm{gm}$. of edible matter, and that the green fruit contained more ascorbic acid than the ripe. Values as high as $4.676 \mathrm{gm}$. per $100 \mathrm{gm}$. of edible pulp of green fruit were reported by H. Mustard (3).

The reaction involved in the Lane-Eynon method (4) for determining reducing and total sugars is one of oxidation and reduction. When this method was used with 25 samples of West Indian cherry juice, it was found that reducing sugars were higher than total sugars. Therefore, the method had to be modified for this specific juice. Ascorbic acid, which is present in large amounts in West Indian cherry juice, is a reducing substance which reacts with the Soxhlet solution as well as the methylene blue used in the Lane-Eynon method. Some ascorbic acid is lost during the process of inversion and, therefore, its contribution when determining reducing sugars is higher than when determining total sugars, making the value for total sugars appear to be smaller than that for reducing sugars.

\section{EXPERIMENTAL PROCEDURE}

Several attempts were made to titrate the Soxhlet solution directly with pure ascorbic acid solution, but it was impossible to obtain end points which checked. However, when a pure solution of ascorbic acid and glucose was prepared the determination was possible. The results are given in table 1 , which shows that ascorbic acid affects the determination of glucose, giving higher jesults than the true value. The factor $(F)$, glucose corresponding to $1 \mathrm{mg}$. of ascorbic acid, was found to be $0.686 \mathrm{mg}$.

To check whether this factor $(F), 0.686 \mathrm{mg}$., could be applied in work

\footnotetext{
${ }_{1}^{1}$ Associate Chemist, Agricultural Experiment Station, University of Puerto Rico, Río Piedras, P. R. The author wishes to express his appreciation to F. Aróstegui and C. G. Móscoso who supplied the fruits necessary for the work. A special debt of gratitude is owed to F. Sánchez-Nieva for supplying the juices and to Josefina Escabí-Agostini for her help in the analytical work.

${ }^{2}$ Numbers in parentheses refer to Literature Cited, p. 205.
} 
with solutions of invert sugars, the following experiment was conducted:

Five $100 \mathrm{ml}$. volumetric flasks containing the same quantity of sucrose and different quantities of ascorbic acid, and $0.50 \mathrm{ml}$. of $\mathrm{HCl}$ (specific gravity 1.19) were left at room temperature for 24 hours. Then they were diluted to volume. Immediately prior to the titration of the Soxhlet solu-

TABLE 1.-Quantity of glucose corresponding to $1 \mathrm{mg}$. of ascorbic acid as determined on a solution of pure ascorbic acid and glucose

\begin{tabular}{c|c|c|c|c}
\hline $\begin{array}{c}\text { Glucose actually } \\
\text { present per 100 mls. } \\
\text { (milligrams) }\end{array}$ & $\begin{array}{c}\text { Ascorbic acid } \\
\text { actually present per } \\
\text { 100 mls. }\end{array}$ & $\begin{array}{c}\text { Glucose } \\
\text { found per } \\
100 \text { mls. }\end{array}$ & $\begin{array}{c}\text { Glucose apparently } \\
\text { plesent due to effect } \\
\text { of ascorbic acid }\end{array}$ & $\begin{array}{c}F \text { (glucose } \\
\text { corresponding to 1 } \\
\text { mg. ascorbic acid) }\end{array}$ \\
\cline { 2 - 4 } 252.8 & Milligrams & Milligrams & Milligrams & Milligrams \\
252.8 & 0.0 & 252.8 & 0.0 & - \\
252.8 & 93.0 & 316.0 & 63.2 & 0.680 \\
252.8 & 143.6 & 351.8 & 99.0 & .689 \\
252.8 & 195.9 & 387.6 & 134.8 & .688 \\
Average.......... & 291.6 & 453.5 & 200.7 & .688 \\
\hline
\end{tabular}

TABLE 2.-Data from an experiment carried out to determine whether the same $F$ factor, $0.686 \mathrm{mg}$., could be used for invert-sugar as for reducing-sugar solutions

\begin{tabular}{|c|c|c|c|c|c|c|}
\hline $\begin{array}{l}\text { Invert sugar } \\
\text { actually present } \\
\text { per } 100 \text { mls. } \\
\text { final dilution } \\
\text { (milligrams) }\end{array}$ & $\begin{array}{l}\text { Invert sugar } \\
\text { per } 100 \mathrm{mls} \text {. } \\
\text { final dilution } \\
\text { found by } \\
\text { titration }\end{array}$ & $\begin{array}{l}\text { Ascorbic } \\
\text { acid added } \\
\text { per } 100 \\
\text { mls. final } \\
\text { dilution }\end{array}$ & $\begin{array}{l}\text { Ascorbic acid } \\
\text { per } 100 \mathrm{mls} . \\
\text { final dilution } \\
\text { found after } \\
\text { inversion }\end{array}$ & \begin{tabular}{|c} 
Ascorbic acid \\
lost in 100 \\
mls. of \\
original \\
solution \\
during \\
inversion
\end{tabular} & $\begin{array}{l}\text { Invert sugar } \\
\text { apparently } \\
\text { present due to } \\
\text { effect of } \\
\text { ascorbic acid }\end{array}$ & $\begin{array}{l}\text { Invert sugar } \\
\text { found per 100 } \\
\text { mls. of final } \\
\text { dilution when } \\
\text { corrected for } \\
\text { ascorbic acid }\end{array}$ \\
\hline & Milligrams & Milligrams & Milligrams & Milligrams & Willigrams & Milligrams \\
\hline 200 & 263.9 & 106.6 & 91.4 & 76.0 & 63.1 & 200.8 \\
\hline 200 & 293.4 & 145.3 & 129.9 & 77.0 & 89.6 & 203.8 \\
\hline 200 & 370.3 & 255.1 & 249.9 & 27.0 & 172.3 & 198.0 \\
\hline 200 & 264.9 & 99.5 & 91.6 & 39.4 & 63.2 & 201.7 \\
\hline 200 & 327.6 & 199.0 & 191.8 & 41.0 & 132.3 & 195.3 \\
\hline Average. & & & & & & 199.9 \\
\hline
\end{tabular}

tion, $50 \mathrm{ml}$. from each flask were pipetted into five volumetric flasks of $250 \mathrm{ml}$., neutralized with sodium hydroxide solution, and diluted to volume. These solutions were used to titrate the Soxhlet solution. Immediately after titrating, the ascorbic acid present in the solution was determined by the iodate method (5). The results are given in table 2 and show that, after correcting for the ascorbic acid present after inversion, the invert sugar found corresponded to the true amount present. This proves that the factor used for reducing-sugar solutions could be used for invert-sugar solutions. 
In table 3 results are given of an analysis made for reducing sugars in solutions containing sucrose, glucose, and different quantities of ascorbic acid. After determining reducing sugars by the Lane-Eynon method and correcting for the ascorbic acid present, the reducing sugars found corresponded to the glucose known to be present.

The same procedure was followed with the West Indian cherry juice, that is, the ascorbic acid was determined both before and after inversion, and then the determination of sugars by the Lane-Eynon method was corrected accordingly.

Five different samples of juices were stored at room temperature and at $45^{\circ} \mathrm{F}$. Determinations of ascorbic acid, reducing sugars, and total sugars were performed periodically. The results are shown in table 4 .

TABLE 3.-Data from an experiment carried out to determine reducing sugars in solutions containing known quantities of sucrose, glucose, and ascorbic acid

\begin{tabular}{c|c|c|c|c|c}
\hline $\begin{array}{c}\text { Glucose added } \\
\text { per 100 mls. } \\
\text { (milligrams) }\end{array}$ & $\begin{array}{c}\text { Sucrose } \\
\text { added per } \\
100 \mathrm{mls} .\end{array}$ & $\begin{array}{c}\text { Reducing sugar } \\
\text { per 100 mls. } \\
\text { found by titration }\end{array}$ & $\begin{array}{c}\text { Ascorbic acid } \\
\text { added per } \\
100 \mathrm{mls} .\end{array}$ & $\begin{array}{c}\text { Reducing sugar } \\
\text { apparently pres- } \\
\text { ent due to effect } \\
\text { of ascorbic acid }\end{array}$ & $\begin{array}{c}\text { Reducing sugar } \\
\text { corrected for } \\
\text { ascorbic acid }\end{array}$ \\
\cline { 1 - 2 } 290.3 & Milligrams & Milligrams & Milligrams & Milligrants & Milligrams \\
290.3 & 199.5 & 374.0 & 128.4 & 88.6 & 285.4 \\
\hline
\end{tabular}

\section{DISCUSSION}

The data in table 4 show that the only difference obtained by storing the juice at room temperature and at $45^{\circ} \mathrm{F}$. was that the ascorbic acid is lost less readily at $45^{\circ} \mathrm{F}$. than at room temperature.

Statistical analysis of the data obtained from the different juices showed that there was no significant difference between corrected reducing sugars and corrected total sugars. It also proved that the lengths of the storage periods were not significant, that is, the sugar content did not change after storing for 1 year. The statistical analysis revealed that, if sucrose is present in the juice, it must be in quantities so small that it cannot be determined by this method. The results had to be expressed to only one decimal place, since the standard error for the determination of sugar in this juice was \pm 0.21 and the least significant difference at 5 percent was \pm 0.42 .

It can be concluded that, in the specific case of the West Indian cherry juice, when using the Lane-Eynon method and correcting for ascorbic acid, reâucing sugars are equal to total sugars and that by determining the former, the sugar content of the juice is known. This eliminates the trouble of having to determine total sugars and ascorbic acid after inversion. However, in any other fruit juice which is rich in ascorbic acid and which con- 
TABLE 4.-Determination of sugars in samples of West Indian cherry juice held at room temperature and at $45^{\circ} \mathrm{F}$.

\begin{tabular}{|c|c|c|c|c|}
\hline $\begin{array}{c}\text { Age of juice } \\
\text { (months) }\end{array}$ & $\begin{array}{l}\text { Corrected reducing } \\
\text { sugar }\end{array}$ & $\begin{array}{l}\text { Corrected total } \\
\text { sugars }\end{array}$ & $\begin{array}{l}\text { Ascorbic acid per } 100 \\
\text { ml. of juice before } \\
\text { inversion }\end{array}$ & $\begin{array}{l}\text { Ascorbic acid per } 100 \\
\text { ml. of juice after } \\
\text { inversion }\end{array}$ \\
\hline \multicolumn{5}{|c|}{ Sample 1, room temperature } \\
\hline & Percent & Percent & Milligrams & Milligrams \\
\hline 0 & 3.6 & 3.7 & 1,120 & 934 \\
\hline 1 & 3.6 & 3.6 & 1,060 & 855 \\
\hline 2 & 3.6 & 3.7 & 1,060 & 734 \\
\hline 3 & 3.7 & 3.6 & 975 & 802 \\
\hline 6 & 3.7 & 3.7 & 744 & 651 \\
\hline 12 & 3.7 & 3.6 & 524 & 464 \\
\hline \multicolumn{5}{|c|}{ Sample $1,45^{\circ} \mathrm{F}$. } \\
\hline 0 & 3.6 & 3.7 & 1,120 & 934 \\
\hline 1 & 3.5 & 3.6 & 1,120 & 995 \\
\hline 2 & 3.6 & 3.6 & 1,180 & 974 \\
\hline 3 & 3.6 & 3.5 & 1,120 & 1,010 \\
\hline 6 & 3.7 & 3.8 & 1,020 & 883 \\
\hline 12 & 3.5 & 3.4 & 1,010 & 859 \\
\hline
\end{tabular}

Sample 2, room temperature

\begin{tabular}{r|l|l|l|l}
\hline 0 & 3.0 & 3.0 & 913 & 796 \\
1 & 3.0 & 3.0 & 874 & 634 \\
2 & 3.0 & 3.2 & 794 & 577 \\
3 & 3.0 & 3.2 & 770 & 430 \\
6 & 3.1 & 3.1 & 612 & 475 \\
12 & 3.1 & 3.3 & 371 & 309 \\
\hline
\end{tabular}

Sample $2,45^{\circ} \mathrm{F}$.

\begin{tabular}{r|l|l|l|l}
\hline 0 & 3.0 & 3.0 & 913 & 796 \\
1 & 2.9 & 2.9 & 958 & 823 \\
2 & 3.1 & 3.2 & 897 & 740 \\
3 & 3.0 & 3.1 & 896 & 624 \\
6 & 3.1 & 3.1 & 813 & 684 \\
12 & 3.2 & 3.3 & 723 & 668 \\
\hline
\end{tabular}

Sample 3, room temperature

\begin{tabular}{l|r|r|r|rr}
\hline 0 & 3.4 & 3.6 & 1,030 & 788 & 0 \\
1 & 3.4 & 3.5 & 970 & 748 & \\
2 & 3.4 & 3.4 & 868 & 691 & \\
3 & 3.5 & 3.6 & 854 & 562 \\
\hline
\end{tabular}


TABLE 4.-Continued

\begin{tabular}{|c|c|c|c|c|}
\hline $\begin{array}{l}\text { Age of juice } \\
\text { (months) }\end{array}$ & $\begin{array}{c}\text { Corrected reducing } \\
\text { sugar }\end{array}$ & $\begin{array}{l}\text { Corrected total } \\
\text { sugars }\end{array}$ & $\begin{array}{l}\text { Ascorbic acid per } 100 \\
\text { ml. of juice before } \\
\text { inversion }\end{array}$ & $\begin{array}{l}\text { Ascorbic acid per } 100 \\
\text { ml. of juice after } \\
\text { inversion }\end{array}$ \\
\hline \multicolumn{5}{|c|}{ Sample 3 , room temperature-Continued } \\
\hline & Percent & Percent & Milligrams & Milligrams \\
\hline 6 & 3.7 & 3.7 & 670 & 532 \\
\hline 12 & 3.4 & 3.7 & 406 & 200 \\
\hline \multicolumn{5}{|c|}{ Sample $3,45^{\circ} \mathrm{F}$. } \\
\hline 0 & 3.4 & 3.6 & 1,030 & 788 \\
\hline 1 & 3.4 & 3.4 & 1,080 & 938 \\
\hline 2 & 3.4 & 3.3 & 992 & 897 \\
\hline 3 & 3.4 & 3.4 & 985 & 817 \\
\hline 6 & 3.5 & 3.4 & 915 & 801 \\
\hline 12 & 3.5 & 3.7 & 823 & 542 \\
\hline
\end{tabular}

Sample 4, room temperature

\begin{tabular}{|c|c|c|c|c|}
\hline $\begin{array}{r}0 \\
1 \\
2 \\
3 \\
6 \\
12\end{array}$ & $\begin{array}{l}3.5 \\
3.5 \\
3.5 \\
3.4 \\
3.6 \\
3.5\end{array}$ & $\begin{array}{l}3.5 \\
3.4 \\
3.6 \\
3.5 \\
3.7 \\
3.5\end{array}$ & $\begin{array}{r}1,140 \\
1,030 \\
933 \\
907 \\
859 \\
449\end{array}$ & $\begin{array}{l}897 \\
968 \\
780 \\
707 \\
662 \\
365\end{array}$ \\
\hline \multicolumn{5}{|c|}{ Sample $4,45^{\circ} \mathrm{F}$. } \\
\hline $\begin{array}{r}0 \\
1 \\
2 \\
3 \\
6 \\
12\end{array}$ & $\begin{array}{l}3.5 \\
3.4 \\
3.4 \\
3.5 \\
3.7 \\
3.6\end{array}$ & $\begin{array}{l}3.5 \\
3.5 \\
3.4 \\
3.5 \\
3.7 \\
3.7\end{array}$ & $\begin{array}{r}1,140 \\
1,150 \\
1,060 \\
1,060 \\
1,020 \\
901\end{array}$ & $\begin{array}{l}897 \\
951 \\
938 \\
912 \\
872 \\
785\end{array}$ \\
\hline
\end{tabular}

Sample 5, room temperature

\begin{tabular}{r|l|l|l|l}
\hline 0 & 3.4 & 3.4 & - & - \\
1 & 3.4 & 3.5 & 843 & 558 \\
2 & 3.4 & 3.3 & 797 & 599 \\
3 & 3.3 & 3.3 & 741 & 589 \\
6 & 3.3 & 3.4 & 619 & 509 \\
12 & 3.4 & 3.6 & 365 & 301 \\
\hline
\end{tabular}


TABLE 4.-Continued

\begin{tabular}{|c|c|c|c|c|}
\hline $\begin{array}{l}\text { Age of juice } \\
\text { (months) }\end{array}$ & $\begin{array}{l}\text { Corrected reducing } \\
\text { sugar }\end{array}$ & $\begin{array}{l}\text { Corrected total } \\
\text { sugars }\end{array}$ & $\begin{array}{l}\text { Ascorbic acid per } 100 \\
\text { ml. of juice before } \\
\text { inversion }\end{array}$ & $\begin{array}{l}\text { Ascorbic acid per } 100 \\
\text { ml. of juice after } \\
\text { inversion }\end{array}$ \\
\hline \multicolumn{5}{|c|}{ Sample $5,45^{\circ} \mathrm{F}$. } \\
\hline & Percent & Percent & Milligrams & Milligrams \\
\hline 0 & 3.4 & 3.4 & & \\
\hline 1 & 3.3 & 3.4 & 946 & 850 \\
\hline 2 & 3.3 & 3.2 & 901 & 797 \\
\hline 3 & 3.3 & 3.2 & 869 & 788 \\
\hline 6 & 3.4 & 3.3 & 823 & 744 \\
\hline .12 & 3.5 & 3.5 & 759 & 650 \\
\hline
\end{tabular}

tains a significant quantity of sucrose, the corrected total sugars as well as the corrected reducing sugars must be determined.

\section{SUMMARY}

(1) Ascorbic acid is the substance responsible for the discrepancies found in the determination of reducing sugars and total sugars by the Lane-Eynon method. By correcting for ascorbic acid using the factor $(F)$ 0.686, the discrepancy is eliminated and the Lane-Eynon method can be used.

(2) To determine the total sugar content of West Indian cherry juice corrected reducing sugars only need be assayed, because it was proved experimentally and statistically that there is no significant difference between corrected reducing and corrected total sugars.

(3) The sugar content of West Indian cherry juices stored at room temperature and at $45^{\circ} \mathrm{F}$. does not change appreciably after 1 year.

(4) At $45^{\circ} \mathrm{F}$. ascorbic acid is lost less readily than at room temperature, but temperature produces no significant difference in the true sugar content of the juice.

\section{RESUMEN}

(1) La substancia responsable de las discrepancias encontradas en la determinación de azúcares reductoras y azúcares totales por el método de Lane-Eynon es el ácido ascórbico. Si se corrige para el ácido ascórbico, usando el factor 0.686, la discrepancia desaparece y el método de LaneEynon es aplicable.

(2) Para conseguir el contenido de azúcares en el jugo de acerola, lo único que hay que determinar son los azúcares reductores corregidos, ๑ya que se ha probado experimental y estadísticamente que no hay ninguna diferencia significativa entre azúcares reductores corregidos y azúcares totales corregidos. 
(3) El contenido de azúcares en el jugo de acerola almacenado a $45^{\circ} \mathrm{F}$ y a temperatura de salón no varía después de 1 año.

(4) Cuando el jugo de acerola se almacena a $45^{\circ} \mathrm{F}$ la cantidad del ácido ascórbico disminuye con menos prontitud que cuando se almacena a temperatura de salón. Sin embargo la temperatura no afecta significativamente el contenido de azúcares en el jugo.

\section{LITERATURE CITED}

1. Asenjo, C. F. and Moscoso, C. G., Food Res. 15 (2) 1031950.

2. Asenjo, C. F. and Freire de Guzmán, A. R., Science 1032191946.

3. Mustard, M. J., Science 1042301946.

4. Lane, J. H. and Eynon, L., J. Soc. Chem. Ind. 42325 1923; J. Assoc. Off. Agr. Chem. 935 1926; 1238 1929; 25991942.

5. Ballantine, R., Ind. Eng. Chem., Anal. Ed. 13891941. 